\title{
Dynamic Simulation of Fuel Cell Driven by Wind Turbine Using Simulink / Matlab Approach
}

\author{
Samuel Sami ${ }^{1,2}$, Cristian Cango ${ }^{1}$, Edwin Marin ${ }^{1}$ \\ ${ }^{1}$ Research Center for Renewable Energy, Catholic University of Cuenca, Cuenca, Ecuador \\ ${ }^{2}$ TransPacific Energy, Inc, Las Vegas, USA
}

Email address:

dr.ssami@transpacenergy.com (S. Sami)

\section{To cite this article:}

Samuel Sami, Cristian Cango, Edwin Marin. Dynamic Simulation of Fuel Cell Driven by Wind Turbine Using Simulink / Matlab Approach. International Journal of Sustainable and Green Energy. Special Issue: Hybrid Systems for Power Generation in Remote Areas. Vol. 9, No. 1, 2020, pp. 1-15. doi: 10.11648/j.ijrse.20200901.11

Received: February 27, 2020; Accepted: March 9, 2020; Published: March 17, 2020

\begin{abstract}
A dynamic numerical simulation has been carried out using the Matlab Simulink tool for simulation of a hybrid Power generation system using wind turbine $(400 \mathrm{w})$ and a fuel cell of Proton Exchange Membrane (PEM). The system has a battery banc to store excess energy not consumed by the load, and an electrolyzer when wind power is unavailable. The numerical model has been developed through blocks of Simulink that contains the data and the system parameters, considering the different elements and characteristics of the different elements of the system. The hybrid system supplies at least 3 hours a day, at $2000 \mathrm{Whr} /$ day. Experiments were conducted using PEM fuel cell type to collect different characteristics of the hybrid system. It was found that the hybrid system efficiency can be increased using more fuel cells in series and the active area of the battery. The numerical model that has been represented in Simulink / Matlab and was validated with the experimental data obtained after the fuel Cell setup. Good agreement has been obtained between the experimental data and the model presented.
\end{abstract}

Keywords: Wind Turbine, PEM Fuel Cell, Dynamic Simulation, MATLAB Simulink and Model Validation

\section{Introduction}

Wind generation has been increasing over recent years, because they are considered as effective means to control and reduce the emissions to the environment, and this type of power generation is one of the most viable solutions to reduce emissions and generate green energy. It has been reported extensively in the literature that power generation with wind turbine using renewable sources are the most environmentally sound technology [1-19].

There are different types of fuel cells, in this research work, the PEM fuel cell is used in low temperature applications. Proton-exchange membrane fuel cells, also known as polymer electrolyte membrane, and also known as polymer electrolyte membrane fuel cells, are a type of fuel cell being developed mainly for transport applications, as well as for stationary fuelcell applications and portable fuel-cell applications as reported by Martinez Reyes [12]. Fuel cells can be classified by different parameters such as temperature, fuel and oxidant used, if fuel direct or indirect, or the electrolyte. Also, can be classified by the working temperature. Therefore, fuel cells can be divided into two groups, low temperature and high temperature, as per Martinez Reyes [12]. In the lowtemperature fuel cells, working temperatures range between $20^{\circ} \mathrm{C}$ and $100^{\circ} \mathrm{C}$. PEM cells use fuel as hydrogen, and oxygen as an oxidant to initiate the chemical reaction that releases electrons which pass through external power circuit. The PEM fuel cell uses water, which was considered as one of the fluids friendlier to the environment Khater, Abdelraouf, Beshr, [4].

On the other hand, Ogawa, Takeuchi, \& Kajikawa [6] analyzed the several publications on about fuel cell systems that work with electrolysers. Reference [6] reported on an increase in the percentage of efficiency at an optimal level, although more work is needed for the automotive industry. Moreover, reference [6] has not performed electrolyzers studies or on the PEME type and any other type electrolyzer.

Our research at the University is intended to enhance our experience of the PEM fuel cell integrated together with other power generation systems such as wind, solar, biomass, tidal wave, etc. In the renewable energy center (CER) of the Catholic University Cuenca, research has been done on hybrid systems-based PV solar panels with fuel cells to 
determine the efficiency of different types of load power as reported by Sami and Marin [9].

In Esmaeili and Shafiee, [2], a hybrid system used a small power cogeneration composed of wind power, solar and fuel cell, in which the interaction between different sources of energy can be seen to compensate a one source when the other 2 sources do not have the necessary energy and to maintain an electric load. Also, Onar, Uzunoglu, and Alam [7] developed a system that is very similar to that of Esmaeili and Shafiee [9] that does not with use the solar panels to power the electrolyzers output voltage level.

In a research carried out by Khan \& Iqbal [3]. they proposed a power generation system that simpler with high capacity generation, using only wind energy combined with a fuel cell for powering a variable load in time, and also used ultracapacitors to compensate for sudden load fluctuations and avoid failures. However, one disadvantage had been faced that with no or little wind, the electrolyzer could not generate the hydrogen needed for fuel cell activation. In their system, the output voltage level of the fuel cell was $65 \mathrm{~V}$ nominal, in which case it activated flow controller to allow the passage of more fuel hydrogen as per Khan \& Iqbal [3].

In reference [17], a wind turbine model for wind energy conversion system study was presented. The turbine static characteristics were modeled using the relationship between the turbine power, the wind speed and the blade pitch angle. The dynamic characteristics of the wind turbine were also modeled through a two-mass oscillating system, that represented the mechanical coupling of the turbine and the generator. The turbine performance was subjected to a real wind speed pattern by modeling the wind speed as a sum of harmonics with wide ranges of frequency. The turbine model included the effect of the tower shadow and wind shear. A pitch angle controller was designed to protect the coupled generator by limiting the turbine output power to the rated value. Simulation results were also reported to verify the wind turbine simulator performance.

Reference [18], in his thesis proposed models that were developed for positive-sequence phasor time-domain dynamic simulations and were implemented in the standard power system simulation tool PSS/E with a $10 \mathrm{~ms}$ time step. The accuracy of the response by the proposed models was validated against the detailed models results and, in some cases, against field measurement data. A direct solution method was proposed for initializing a DFIG wind turbine model. A model of a DC-link braking resistor with limited energy capacity was proposed, thus, a unified model of a FCWT for a power system stability analysis can be obtained. The results showed that the proposed models were able to simulate wind turbine responses with sufficient accuracy. The generic models proposed in his thesis can be seen as a contribution to the ongoing discourse on standardized models of wind power generation for power system stability studies.

One of the main reasons for conducting this study is because Fuel Cell driven by wind turbine has less no negative direct environmental impact compared to other types of power generation. In addition, this particular hybrid system is suitable to supply power in remote areas where new power lines are costly and difficult to erect. The simulation of the system presented hereby took into account the nominal power generation turbine $(400 \mathrm{~W})$ and a $650 \mathrm{~W}$ load that could be fed during the day, but the simulation used on the average time of 3 hours to represent time of consumption for one day, with the total and the total consumption per day was $2000 \mathrm{Wh}$.

The dynamic simulator was built with the help of the platform Matlab /Simulink [20]. This allows to develop a simulator platform Matlab / Simulink and visualize how the system behaves with the variation of different parameters. Secondly, a computational algorithm was developed for the simulation of the behavior of the fuel-cell. And, finally, the hybrid system was analyzed and validated using data on wind turbine and fuel-cell set up.

\section{Mathematical Model: Hybrid Wind Turbine and PEM Fuel Cell System}

In this section, the different equations and formulas used to develop the simulated system platform Simulink / Matlab [20] are presented. The general hybrid system is composed of different elements/subsystems that were shown in Figure 1. In the following, we present the different mathematical equations describing the behavior of each element/subsystem.

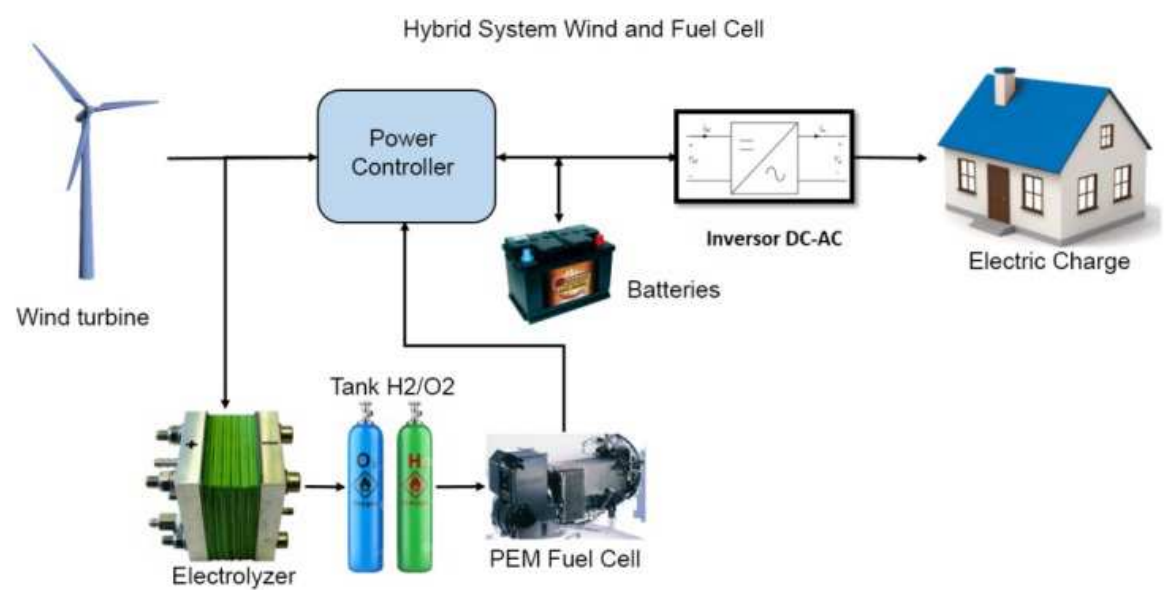

Figure 1. Different components of the hybrid system in question. 
As shown in Figure 1, the wind turbine activated the electrolyzer and in turn generated the hydrogen and oxygen where was stored in separate tanks and in turn energy was sent to the power controller, the stored hydrogen and oxygen were used in the fuel cell for generating DC power. The power generated by the fuel cell stack was directed to the load controller where the control strategy was realized. Then, total power that in the load controller was directed to the inverter to convert to AC power. The battery bank function was to store power to compensate when the load is less generated and also when the wind turbine system was unable to harness this wind energy, due to low wind speeds, and whereby, the batteries can feed the electrolyzer.

\section{Numerical, Model}

\subsection{Wind Turbine}

The wind turbine implemented in this study can extract maximum power at wind speed of $17.9 \mathrm{~m} / \mathrm{s}$. when this speed was exceeded the turbine will lock to prevent over-speed at the turbine. This may be damaging to the wind turbine according to wind power curve of the wind turbine. This wind power curve was obtained from the manufacturer AIR403 [19], therefore, this wind power curve results were used in this simulation.

To obtain the power generated by the wind turbine simulator, the following transfer function developed by Khan \& Iqbal, [15] was used.

$$
\frac{y(s)}{x(s)}=0.25 /\left(s^{2}+0.7 s+0.25\right)
$$

Where, $x(t)$ is the power obtained from the power curve for a speed of Wind already established, while $y(t)$ is current power is obtained at the output of the wind turbine by Sami and Garzon, [8]

\subsection{PEM Fuel Cell}

Khan \& Iqbal, [15] stated that the ideal voltage standard of a fuel cell PEM 1.229 V obtained as residual and the battery voltage decays because irreversible losses. The thermodynamic potential was then determined by the equation of Nernst.

$$
\begin{gathered}
E=1.229-0.85 \times 10^{-3}(T-T r)+4.3085 \times 10^{-5} * T * \\
\left(\ln P_{\mathrm{H}_{2}}+0.5 \ln P_{\mathrm{O}_{2}}\right)
\end{gathered}
$$

Where $P_{\mathrm{H}_{2}}$ is the pressure in atmospheres of hydrogen, $P_{\mathrm{O}_{2}}$ is pressure is oxygen and $\mathrm{T}$ is the temperature in degree Kelvin.

$\mathrm{T}$ is the reference temperature $(298.15 \mathrm{~K})$. The concentration of oxygen in the gas or liquid can be defined by the law Henry as shown in (2) by Sami \& Marin [9];

$$
\mathrm{CO}_{2}=\mathrm{PO}_{2} /\left(5.08 \times 10^{6} \exp \left(-\frac{498}{T}\right)\right)
$$

The equations for the voltage needed for activation and internal resistance were developed from empirical analysis by Amphlett, et al. [1] and given as:

$$
\begin{aligned}
\eta_{\text {act }}= & -0.9514+0.00312 T-0.000187 T \ln (i)+ \\
& 7.4 \times 10^{-5} T \ln \left(\mathrm{CO}_{2}\right) \\
R_{\text {int }}= & 0.01605-3.5 \times 10^{-5} \mathrm{~T}+8 \times 10^{-5} i
\end{aligned}
$$

$i$ is the current of the fuel cell, the firing resistor was determined as negative for a positive value $R a$;

$$
R a=-\eta_{a c t} / i
$$

Voltage ohmic losses are given by equation (6) and the following figure 2 presented the graph of the equivalent circuit of the fuel cell, which can be noted that the internal resistance was in series. The voltage drop was considered for calculating the actual voltage that would be off the stack fuel;

$$
\eta_{\text {ohmic }}=-i * R_{\text {int }}
$$

Combining the above equations resulted in the output voltage of the stack and was defined as;

$$
V s=E-v_{a c t}+\eta_{\text {ohmic }}
$$

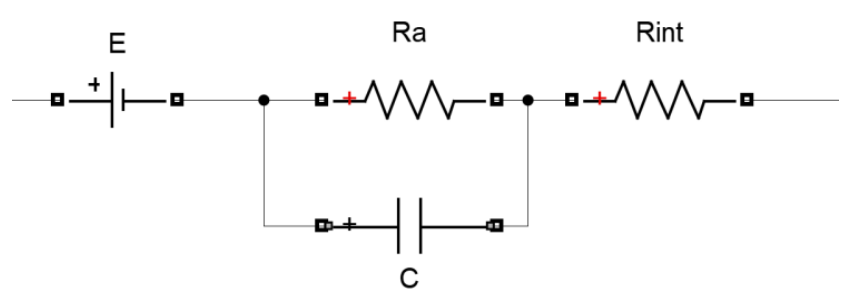

Figure 2. PEM fuel cell electrical circuit.

The output voltage of the fuel cell was described by the differential equation (9), which had as parameters the current required (i) to supply the load and compensate when the wind turbine is not in the ability to provide the necessary power to load.

$$
\frac{d v_{a c t}}{d t}=\frac{i}{C}-\frac{v_{a c t} * C}{R a}
$$

The amount of hydrogen and oxygen consumed by the fuel cell was determined by the current of the fuel cell, in addition to the incoming and outgoing flows ( $\mathrm{mol} / \mathrm{s}$ ), if flows into and out of the hydrogen and oxygen was known, the gas pressures within the humidifier can be described using the principle of conservation of mass. To calculate the pressure of hydrogen and oxygen, equations (10) and (12) were used Knowing the flow rates of hydrogen and oxygen can be described pressure (atm) of the anode with the following equation.

$$
\frac{V_{a}}{R T} \frac{d P_{H_{2}}}{d t}=\dot{m}_{H_{2}}-\left(\rho_{H_{2}} U A\right)_{o u t}-\frac{i}{2 F}
$$

Where $V_{a}$ is the volume in liters, $U$ is the velocity of the fuel, $R$ is the constant of Universal Gas ( 1 atm $0.0821 / \mathrm{mol}$ $\mathrm{K}), \mathrm{T}$ is the temperature in Kelvin degrees $(\mathrm{K}), \rho_{\mathrm{H}_{2}}$ is the molecular hydrogen density, $\mathrm{A}$ is the area of the flow channel 
and $F$ is the constant of Faraday's law. The pressure in the cathode can be calcualted using equation (11),

$$
\frac{V_{c}}{R T} \frac{d P_{O 2}}{d t}=\dot{m}_{O_{2}}-\left(\rho_{O_{2}} U A\right)_{\text {out }}-\frac{i}{2 F}
$$

$V_{c}$ is the volume in liters and the cathode $\rho_{O_{2}}$ is the molecular density of oxygen.

$$
\mathrm{GIC}=\mathrm{ETA}+\mathrm{PCA}
$$

The internal resistance and the current of the fuel cell can be used to calculating internal heat losses

$$
\mathrm{GIC}=i^{2}\left(R_{a}+R_{\text {int }}\right) * \text { ncell }
$$

Where ncell is the number of cells of the fuel cell are in series.

$$
\mathrm{ETA}=C_{t} * d T / d t
$$

Where $C_{t}$ is the heat capacity of the fuel cell stack fuel of the same which is assumed as $10,000 \mathrm{~J} /{ }^{\circ} \mathrm{C}$.

$$
\mathrm{PCA}=T-T_{a} / R_{t}
$$

$T_{a}$ is the temperature and is assumed as $25^{\circ} \mathrm{C}$ and $R_{t}=$ $0.04^{\circ} \mathrm{C}$

\subsubsection{Electrolyzer}

For the decomposition of water into hydrogen and oxygen it was required an electric current between the two electrodes separated by aqueous electrolyte, and was obtained from the following reaction.

$$
\mathrm{H}_{2} \mathrm{O}(1)+\text { electric energy } \rightarrow H_{2}(g)+\frac{1}{2} \mathrm{O}_{2}(g)
$$

The characteristics of the voltage and current of an electrolyzer temperature were dependent upon the operation. Thereof, these characteristics were highly nonlinear, following the lineament Faraday's law, the production of hydrogen in an electrolyzer cell was directly proportional to the number of electrodes transferred to the electrodes, and this in turn, it was equivalent to the electric current in the circuit.

$$
n_{H 2}=\frac{\eta_{F} n_{c} i_{e}}{2 F}(\mathrm{~mol} / \mathrm{s})
$$

Where $i_{e}$ is the current of the electrolyzer, $n_{c}$ is the number of cells in series and electrolyser $\eta_{F}$ is the Faraday efficiency to calculate the efficiency Faraday used the following equation.

$$
\eta_{F}=96.5 \exp \left(0,09 / i_{e}-75.5 /\left(i_{e}^{2}\right)\right)
$$

The Faraday efficiency is the relationship between the current and the maximum amount of hydrogen produced in the electrolyzer.

\subsubsection{Ultra-capacitor}

The ultra-capacitor was used to compensate for sudden changes in voltage and current load, because in this energy was stored. The ultra-capacitor can be modeled with the transfer function as follow;

$$
\frac{V_{u c a p}}{V_{\text {Fcell }}}=\frac{s+1 / R_{C} C}{s\left(1+\frac{R_{S}}{R_{C}}\right)+1 / R_{C} C}
$$

Because Simulink allowed the use the aforementioned components directly chose such a solution as shown in Figure 3.

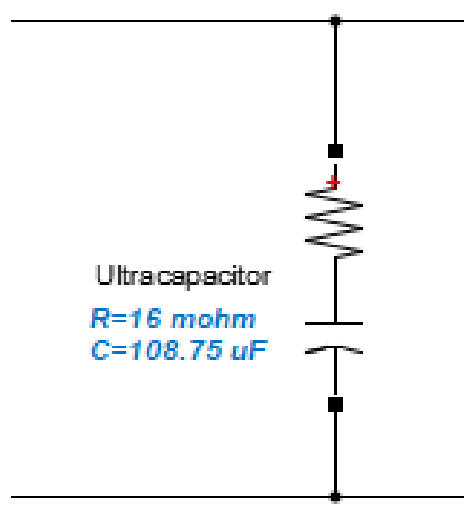

Figure 3. Ultra-capacitor connected in parallel to the fuel cell.

$$
\frac{V_{\text {boost }}}{V_{\text {ucap }}}=\frac{1}{1-D}
$$

For the inverter, a Universal Bridge was adopted from the library Simulink, having as output $120 \mathrm{Vac}$ at a frequency of $60 \mathrm{~Hz}$, a pulse generator used with a PWM carrier wave 1.08 $\mathrm{KHz}$ also was using the single phase, full bridge option 4 pulses.

\subsubsection{Drivers}

PID controllers were used to control the flow of hydrogen and oxygen according to the voltage level having the fuel cell when the voltage of the fuel cell down over $48 \mathrm{~V}$. The controller allowed the passage of a greater flow of hydrogen and oxygen to stabilize the voltage and current. The general transfer function for PID controllers can be described as follows.

$$
G_{r}(s)=\frac{K p\left(s+T_{d} S^{2}+\frac{1}{T_{i}}\right)}{s}
$$

Where all parameter in equation (21) are given in Table 1.

Table 1. Flow controllers' parameters fuel cell.

\begin{tabular}{llll}
\hline & Kp & Ti & Td \\
\hline Fluid 02 & 2,17 & 0,5 & 0 \\
Fluid H2 & 5 & 0,5 & 0 \\
\hline
\end{tabular}

\subsubsection{Hydrogen Storage Tank}

In order to calculate the amount of hydrogen stored, the difference between the quantity produced and consumed was calculated and stored in the tank and can be found by the following equation which can be used calculate the hydrogen pressure directly. It was assumed in the dynamic model that all auxiliary equipment such as valves, pumps, fans or compression were neglected. 


$$
P_{b}-P_{b i}=Z \frac{N_{H 2} * R T_{b}}{M_{H 2} V_{b}}
$$

With equation (23) the efficiency of the fuel cell can be calculated.

Where $V_{S}$ is he output voltage of the fuel cell Marin [5];

$$
\eta_{\text {stack }}=0.83 * \frac{V_{s}}{E}
$$

\subsubsection{Battery Bank}

The power consumption of the electrolyzer was considered in the calculation of the battery bank and was used when the wind turbine does not have the adequate wind speed for operation. Therefore, it activated the electrolyser to generate the necessary hydrogen needed by fuel cell system.

To calculate the charging time of the battery, equation (24) was used and took into account the energy storage capacity of the battery (Ah) and the ability to charge current (A), which can estimate time it to charge the battery.

$$
\mathrm{Tc}(\mathrm{h})=\mathrm{Cb}(\mathrm{Ah}) / \mathrm{Cc}(\mathrm{A})
$$

Where $\mathrm{Tc}=$ Charging time $(\mathrm{h}) \mathrm{Cb}=$ Battery capacity $(\mathrm{Ah})$ $\mathrm{Cc}=$ capacity charger $(\mathrm{A})$

\subsubsection{Energy Control Strategies of the Proposed System}

Figure 4 showed the block diagram that represented the strategy control system for the following operating conditions;

First case: If the power of the load (P load) exceeded the power of the wind turbine and Battery power (P battery) the fuel cell will act. Therefore, the sum of the powers would be as follows.

$$
P_{\text {carga }}=P_{\text {viento }}+P_{\text {batería }}+P_{F C}, P_{\text {sis }}<0
$$

Second case: If the power generated by the wind turbine plus obtained from the battery bank exceeded power load demand, the surplus power will be delivered to the electrolyzer, therefore, the sum of the powers would be as follows.

$$
P_{\text {elec }}=P_{\text {viento }}+P_{\text {batería }}-P_{\text {carga }}, P_{\text {sis }}>0
$$

Third case: If power generation through wind energy obtained more bank Battery was equal to the load requirements, then all the energy generated will directly to the load, having the following equation powers.

$$
P_{\text {load }}=P_{\text {viento }}+P_{\text {batería }}, P_{\text {sis }}>0
$$

\subsection{Flowchart Wind Turbine - Fuel Cell Hybrid System}

The flow chart of the hybrid system of wind turbine-Fuel cell presented in equations (1) through (27) was depicted in Figure 4., Where it was shown that the power received by the controller from the fuel cell, wind turbine and battery was added while the power consumed by the load were subtracted from power delivered to the electrolyzer subsystem. As previously noted, the electrolyzer required energy to produce, to be activated and hydrogen and the fuel cell system.

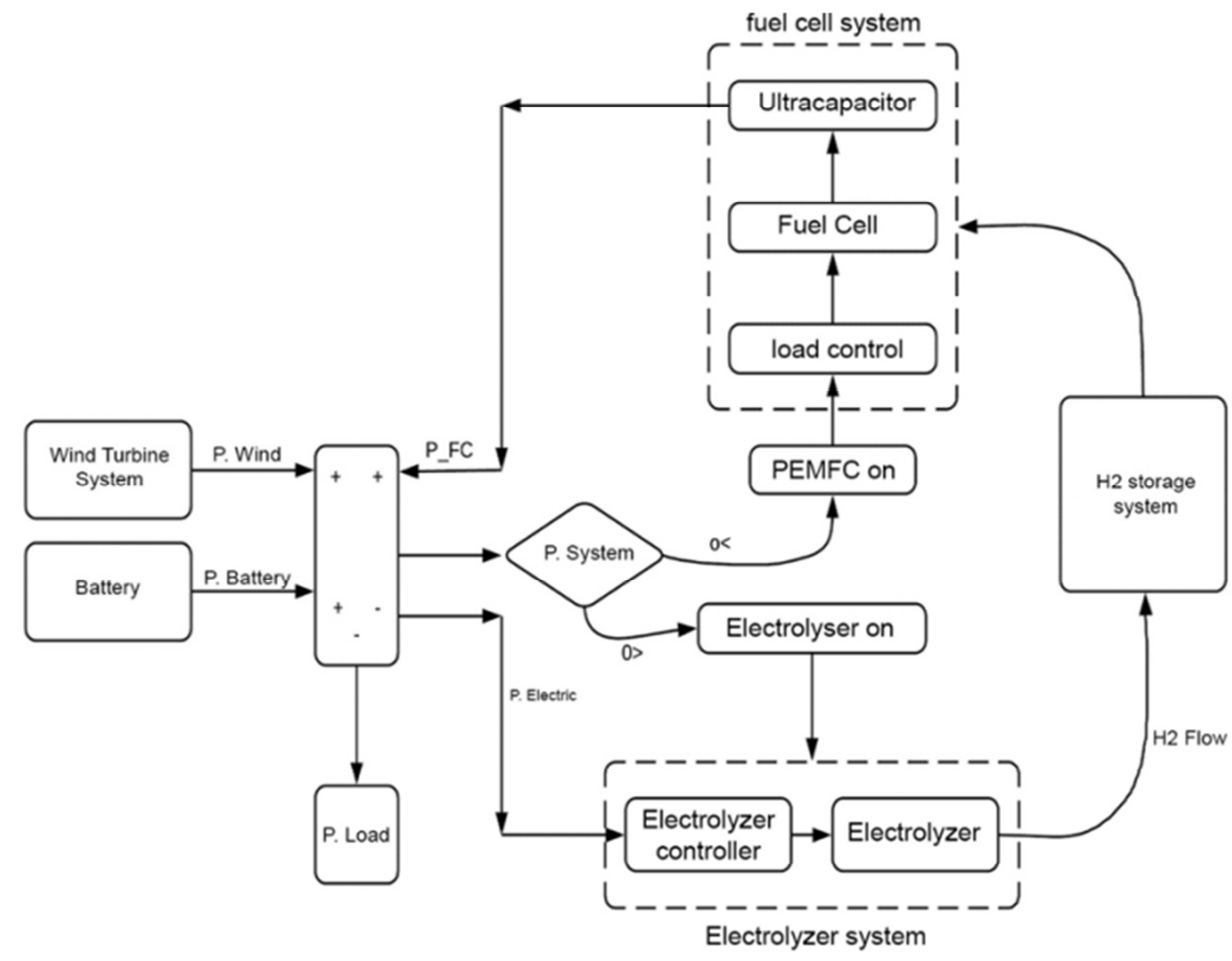

Figure 4. Flowchart of the control scheme of the hybrid wind system fuel cell. 


\section{Results and Discussions: Results of the Simulation Matlab / Simulink and Data Experimental}

In this section, the results of the simulations carried out are presented with screenshots of different power curves, voltages, currents, production of hydrogen, oxygen, load variations, and temperatures. It was assumed in this analysis that the operating temperature of the electrolyzer is $40{ }^{\circ} \mathrm{C}$. The equations (1) through (27) presented a simple model of electrolyzer in which it was assumed that the electrolyzer has a separate cooling system to maintain at $40^{\circ} \mathrm{C}$. To release hydrogen and oxygen, distilled water is used, because it contains ions and has very low or almost no conductivity, these are important characteristics of the distilled water.

\subsection{Wind Profiles}

Wind speeds, and wind direction were collected using a measurement monitoring system, weather station $H O B O$ [21]. Measurement of the wind speeds on obtained on site showed that the wind speed was too low as can be seen in Figure 5. From the Data collected over a period of two months, February and March, one can observe from the results presented in Figure 5 that the average wind speed is too low, with only $1.6 \mathrm{~m} / \mathrm{s}$ to $2.08 \mathrm{~m} / \mathrm{s}$. The average maximum speed of wind gusts was $3.59 \mathrm{~m} / \mathrm{s}$ during the month of March, and the maximum speed was recorded on March 2 at 13:49 hours, having a speed of $4.78 \mathrm{~m} / \mathrm{s}$, but with very short duration.

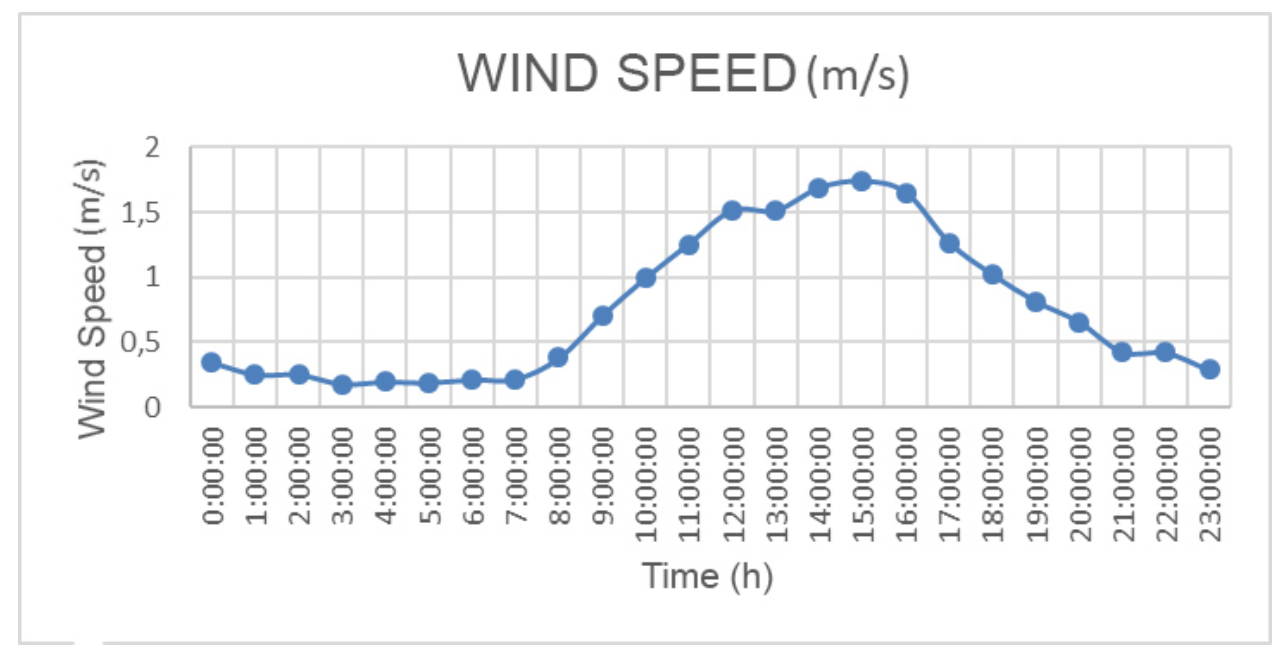

Figure 5. Average wind speed for one day in February, March 2018.

Hybrid Wind and Fuel Cell System

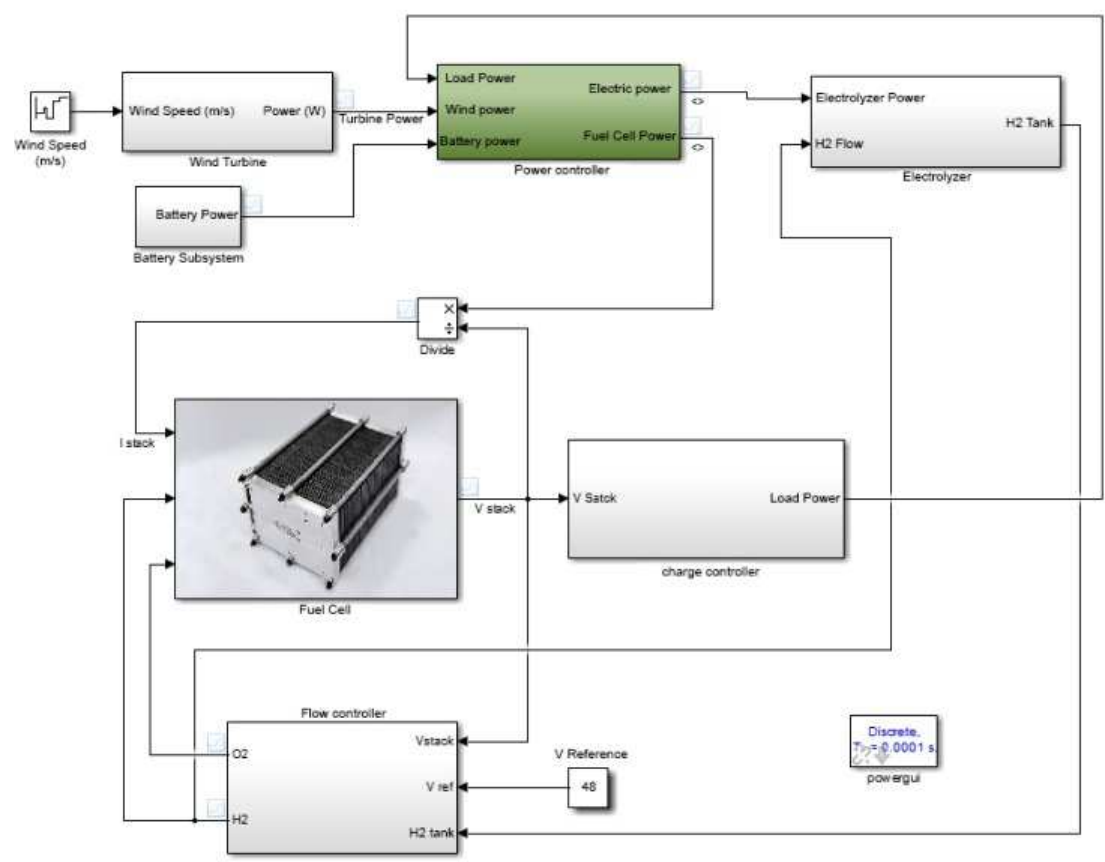

Figure 6. Hybrid system modeling in Matlab Simulink. 


\subsection{Results of Dynamic Simulation of the Wind-battery Hybrid System Fuel}

The performed simulation results are presented and discussed in the following sections and compared with the laboratory tests. Figure 6 displayed the Simulink/Matlab modeling system, which included the several subsystems: fuel cell subsystem, electrolyzer, subsystem flow controller, wind generation subsystem, power controller subsystem, and battery bank subsystem. Because this simulation used parts of Simulink as known as SimPowerSystems, it was necessary to include in the simulation block PowerGUI, where in this block, the data normally were selected in three different ways; Continuous, Discrete and Phasor. In this simulation the option "Discrete" was considered because if the option "Continuous" was used a significant data had to be processed and the system became slow.

Figure 6 showed the power controller in the subsystems for all the powers and was used as a reference. Also, Figure 6 presented the power controller for all the powers such as the wind power battery bank, and load power consumption. The output signals for either the fuel cell or electrolyser depended on the test case considered in the control strategies. The battery bank consisted of four batteries in series $12 \mathrm{VDC}$ and have $70 \mathrm{Ah}$ each and supplied a total voltage of $48 \mathrm{~V}$ nominal and was connected to the power controller. Moreover, the battery bank delivered power the electrolyzer when no and/or low wind to power generation through the turbine were available.

To model the ultra-capacitor, the Maxwell module $435 \mathrm{~F}$ $14 \mathrm{~V}$ has been used and connected in series to obtain the voltage range of the fuel cell, where a resistor and a capacitor were integrated as shown in Figure 7.

The power generation subsystem through the stack fuel has been presented in Figure 8 where the input parameters as the current flow of hydrogen and oxygen, and the battery voltage were displayed. The upconverter used the duty cycle (C. F. equation 22) to raise the output voltage of the fuel cell $(48 \mathrm{~V}-$ $80 \mathrm{v}$ ) to a level of $120 \mathrm{VDC}$ and forwarded to the inverter. The inverter used the block "Universal Bridge" to convert the DC voltage $\mathrm{AC}$ and within the "Power Electronic Device" option used an "Ideal Switches" as well as the inverter that had a pulse generator sent a signal pulse to the inverter bridge fullwave $\mathrm{AC} 120 \mathrm{~V}, 60 \mathrm{~Hz}$, and the signal of the carrier wave was $1080 \mathrm{~Hz}$. The fuel cell subsystem used different equations to determine temperature, pressure that controlled both oxygen and hydrogen. The output voltage of the fuel cell was between 48 and 80 volts. When the voltage dropped below 48 volts, the flow controller allowed the passage of more of hydrogen and oxygen and increased the pressure due to the increased flow in order to have the required voltage. The internal temperature of the fuel cell depended on the current generated, and to obtain the current, the internal resistance and activation resistance was multiplied by the number of resistance cells connected in series. This also considered the temperature of the environment, and in this case, it was assumed as reference of $25^{\circ} \mathrm{C}$.

In Figure 9 showed the relationship between wind speed and power generated, which is known as the wind power-curve and was obtained from the manufacturer manual [21], the diameter of the turbine was $1.14 \mathrm{~m}$ and had an output power of $400 \mathrm{~W}$ when the wind speed was to about $12.5 \mathrm{~m} / \mathrm{s}(28 \mathrm{MPH})$.

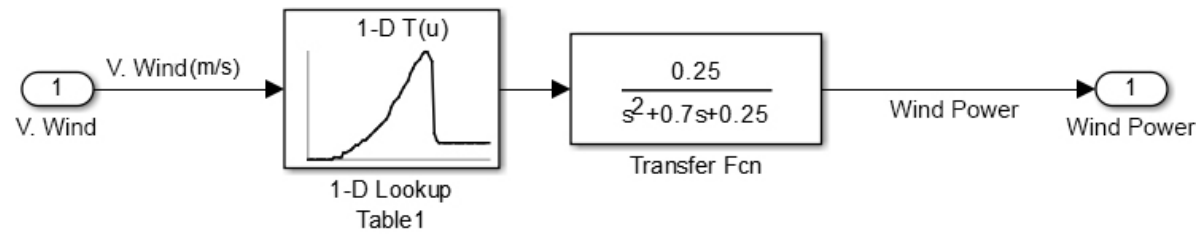

Figure 7. Power curve and transfer function of wind turbine.

The wind power was generated at different speeds of the wind and presented in Figure 9, where the wind speed was plotted against the power generated. The power curve was obtained from the wind turbine manual 403 Air Power [19]. It was also found that the results displayed in the powercurve were consistent with the measured wind speeds.

In Figure 10 the subsystem power generation by the wind turbine has been presented. It can be noted that when the wind speed exceeded $18 \mathrm{~m} / \mathrm{s}$, the embedded protection system of the wind turbine was activated by blocking the blades rotation to avoid no-over speed condition and to protect against system failure. Also, it can be seen from the results displayed in this figure that the battery generated the necessary power to compensate the power difference between the load and the wind turbine output.

The load-power curves were presented in Figures 11 and
12. in this particular case it was estimated a period of three hours took into account that certain electrical appliances on average house were not used all day, therefore, the hybrid system in question can supply an energy demand of 2000 Whr for a constant period of 3 hours with a power of $650 \mathrm{~W}$ load with no issue and having a nominal output power of 400W.

Figure 13 showed a comparison between the power-load stack in the wind turbine, in a home connected constantly at different periods depending on the needs. It can be seen from the results in this figure that in the second $20,25,60,75$, and 85 there was a sudden change in load power, that was caused by the load resistors that were scheduled to change at instantaneous time. It can also be seen in this figure that the power controller adapted the subsystem to the power-load supplied by the fuel cell and wind turbine stack subsystems. 


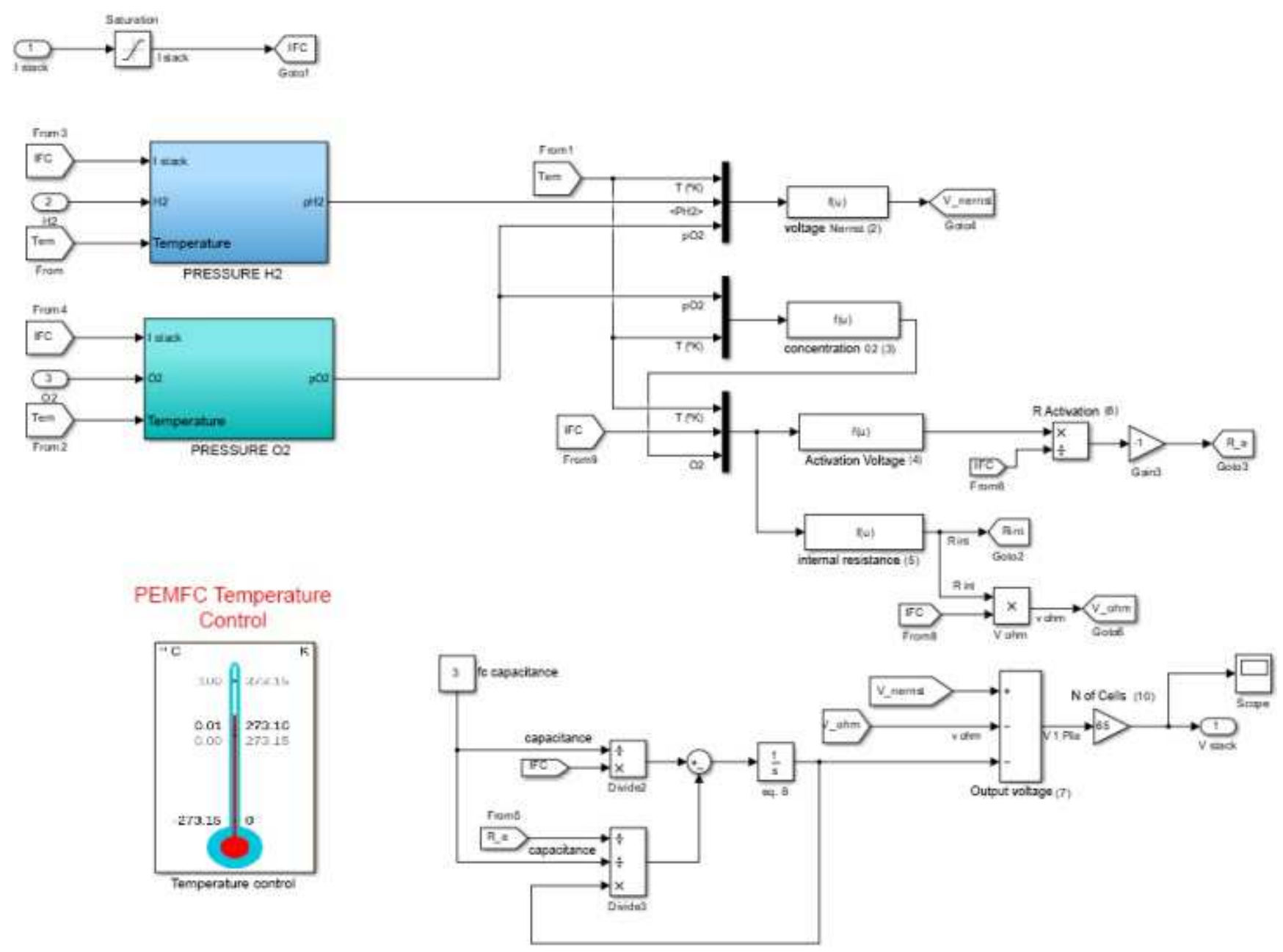

Figure 8. Fuel cell subsystem.

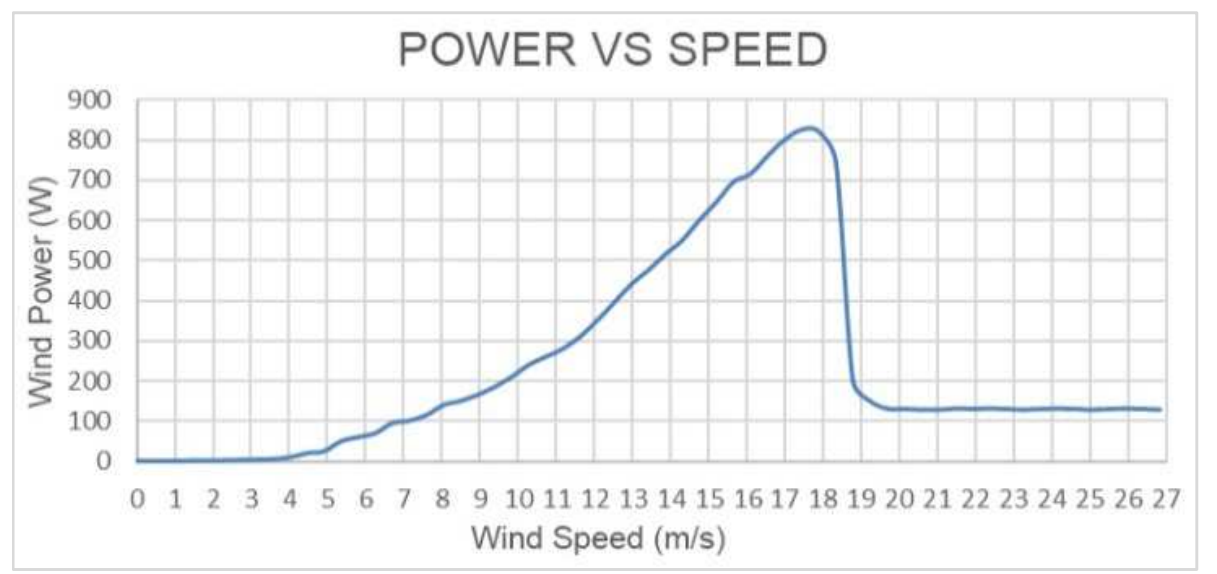

Figure 9. Curve of wind speed and generated power.

As seen in Figure 13 in the second 54 the power generated by the turbine wind exceeded the power required for the load, therefore, the fuel cell did not generate any power, and load was completely satisfied by the wind turbine. The overused power was used in the electrolyzer for hydrogen generation and subsequent energy storage in the tanks. Also, in Figure
13 , it can be observed that the changes in output current of the wind turbine and had similar trends and were observed for the output power.

It can be noted that these variations in the current occurred only when there was a change in wind speed. 


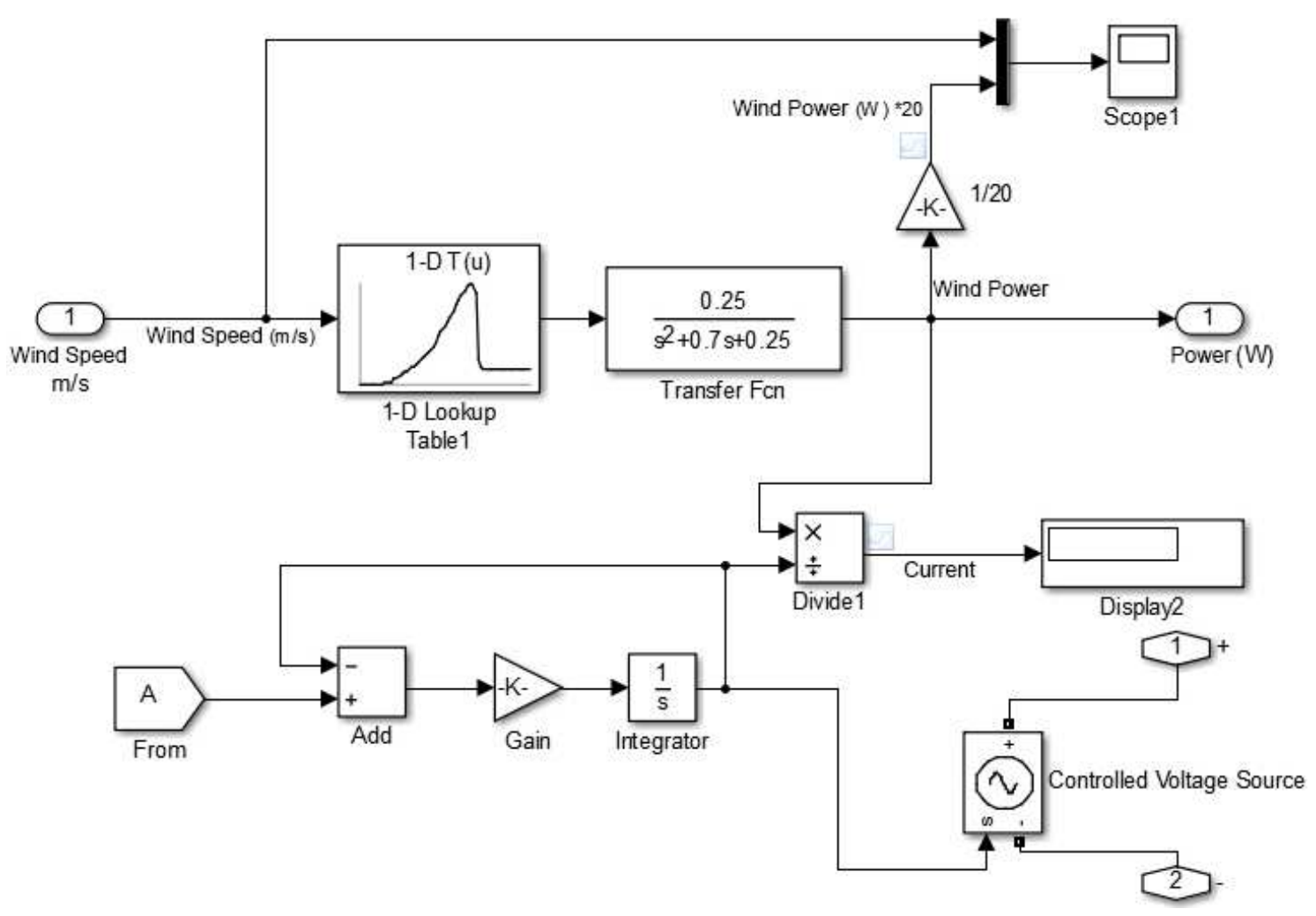

Figure 10. Wind turbine subsystem.

In Figure 14 one can observe the different temperatures of the fuel stack in response to load change and the current to be supplied. Also, it can be seen that the changes in temperature were relatively low, when the battery was not in operation $(t$ $=55 \mathrm{~s}$ from $\mathrm{t}=94 \mathrm{~s}$ ), and the temperature was maintained at $25^{\circ} \mathrm{C}$, which is the room temperature.
Figure 15 showed the variations in pressures of the hydrogen and oxygen of the fuel cell. It was quite clear that the pressure varied from $0 \mathrm{~s}$ to $54 \mathrm{~s}$ time and was dependent on the current needed to be produced, also, during the period of time between $54 \mathrm{~s}$ and $94 \mathrm{~s}$, no generation was observed in hydrogen by the fuel cell.

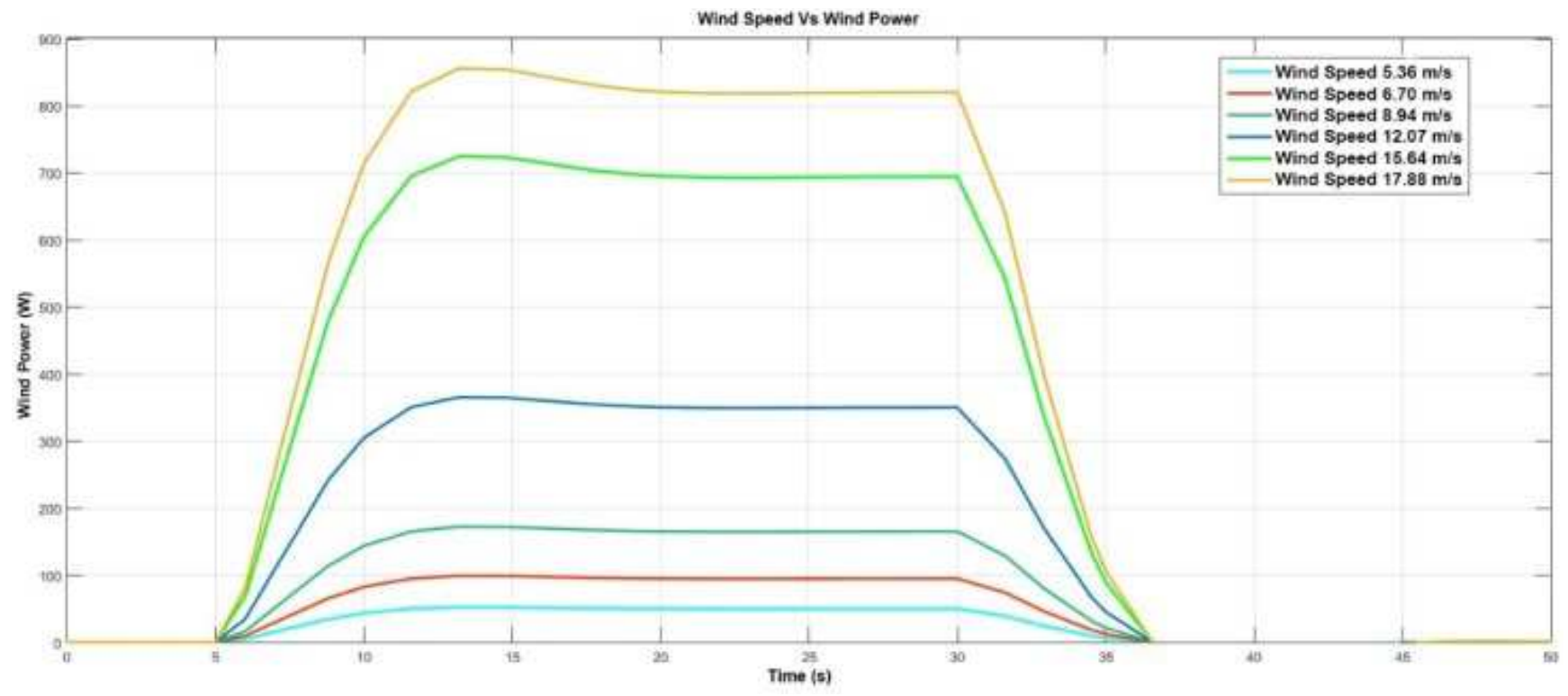

Figure 11. Comparison of power obtained different wind speeds. 


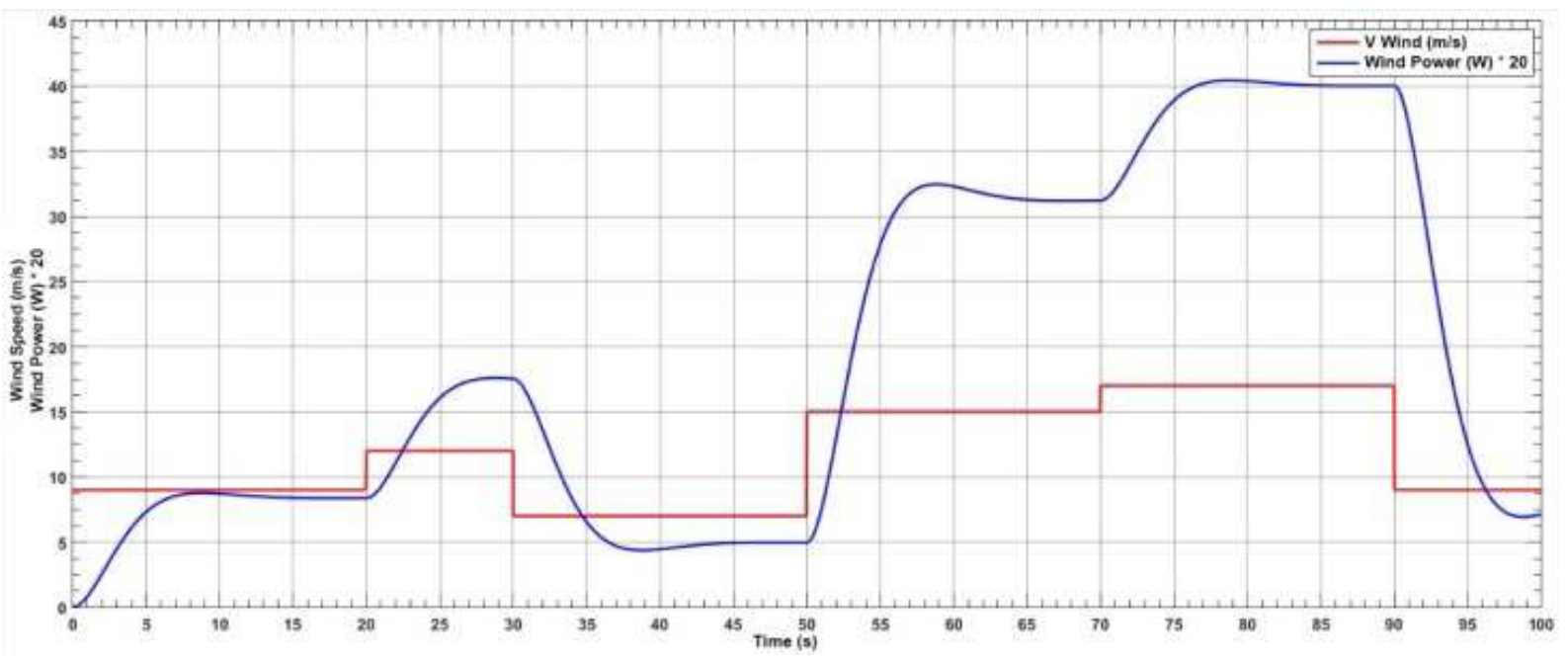

Figure 12. Speed curve wind power generated in the simulation.

It should be noted that the amount of hydrogen generated that was delivered to the stack generation fuel for electricity was shown in Figure 16. This amount of hydrogen increased when the fuel cell needed to generate more power and when the battery output was low. Also, as seen in Figure 16 the voltage output of the boost converter, had experienced a slight drop /and or sudden elevations voltage during simulation, this was caused by the load changes, however, the voltage was restored instantly as seen In Figure 16 where one can observe the output of the inverter voltage at $120 \mathrm{~V}$ and $60 \mathrm{~Hz}$, and had sinusoidal signal, and also it can be noted that in the second 25 output current of the inverter was low when the load resistance rose.

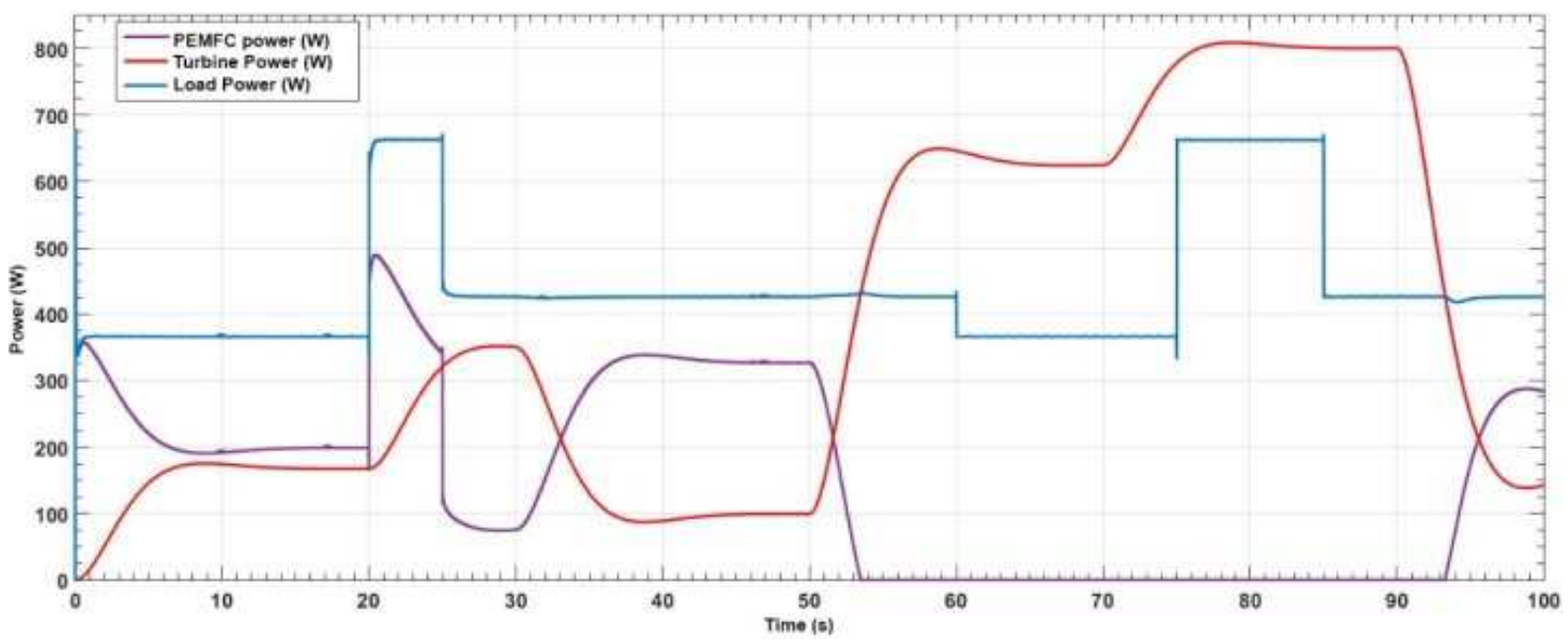

Figure 13. Comparison of powers in the controller.

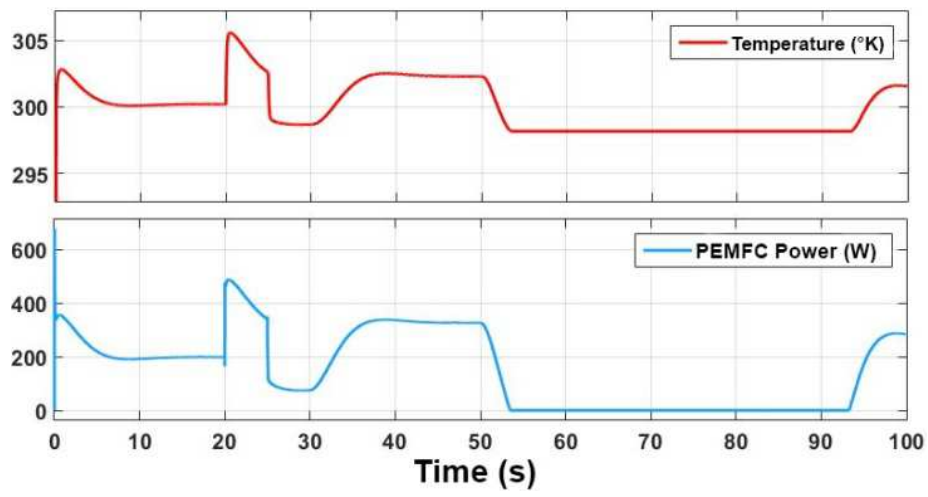

Figure 14. Change in temperature in the fuel cell simulation, response to load change.

Figure 17 showed the load current variation when there was a change of resistance, the current load was supplied in 
part by the wind turbine system and partly by the fuel cell. Figure 17 presented the graph of the load-current and it can be seen that the current varied from $6 \mathrm{~A}$ to $10.5 \mathrm{~A}$ and in the second 20 and second 25 changed from 10.5 A to $7 \mathrm{~A}$, respectively.

Figure 18 presented the discharge-curve of the battery and indicated that the battery can support the constant load for 14 hours and was fully discharged over a period of 21 hours. It should also be noted that the battery bank had 4 batteries in series $12 \mathrm{VDC}$ and $70 \mathrm{Ah}$, and the nominal consumption of the electrolyzer was $5 \mathrm{~A}$ to $48 \mathrm{~V}$.

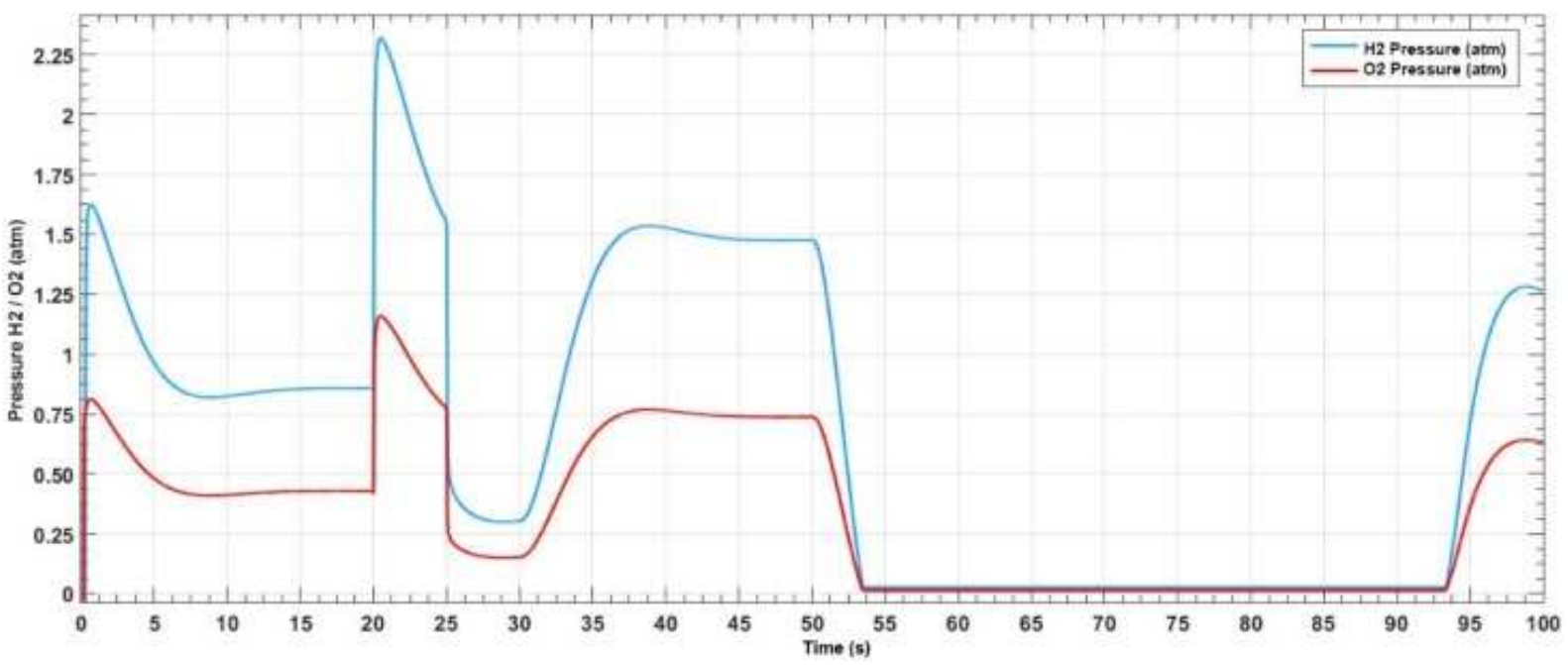

Figure 15. Pressure hydrogen and oxygen fuel cell simulation.

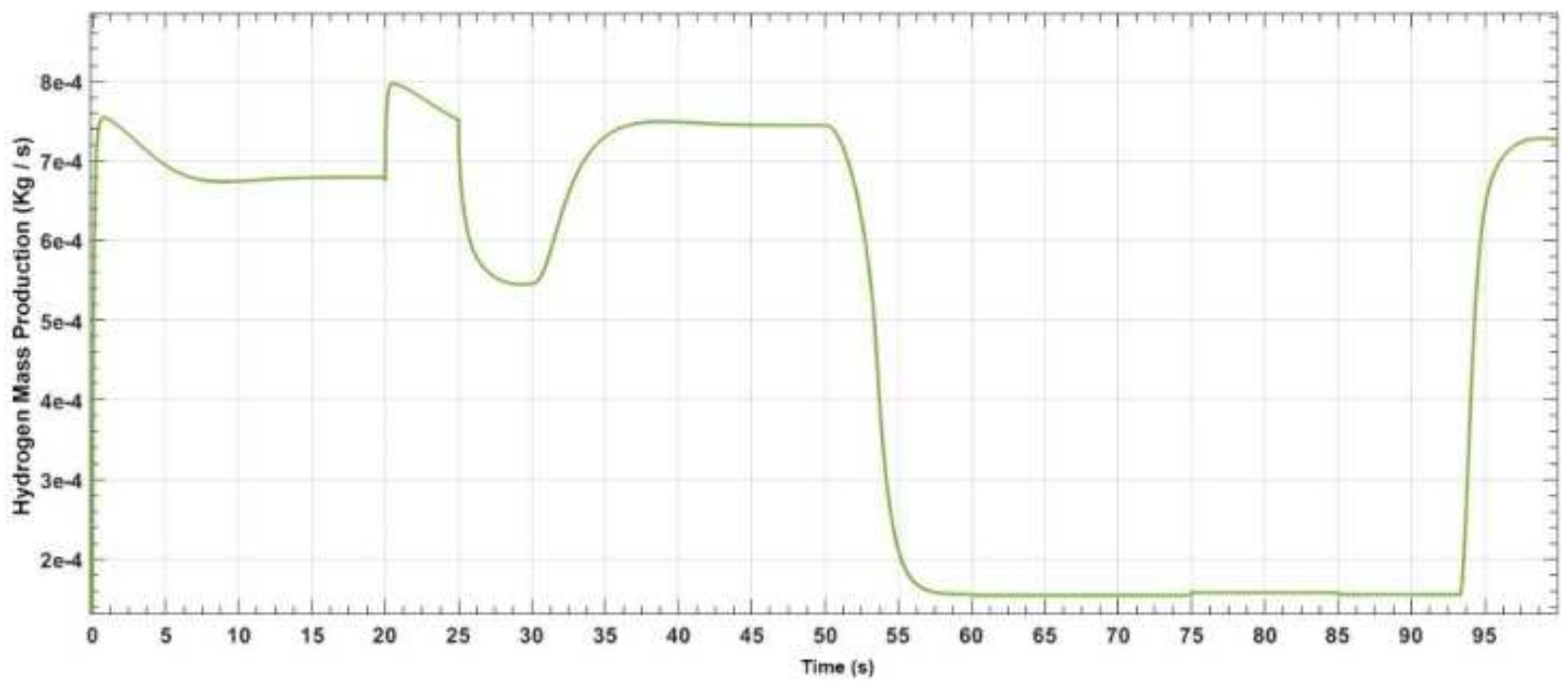

Figure 16. Mass hydrogen produced by the electrolyzer.

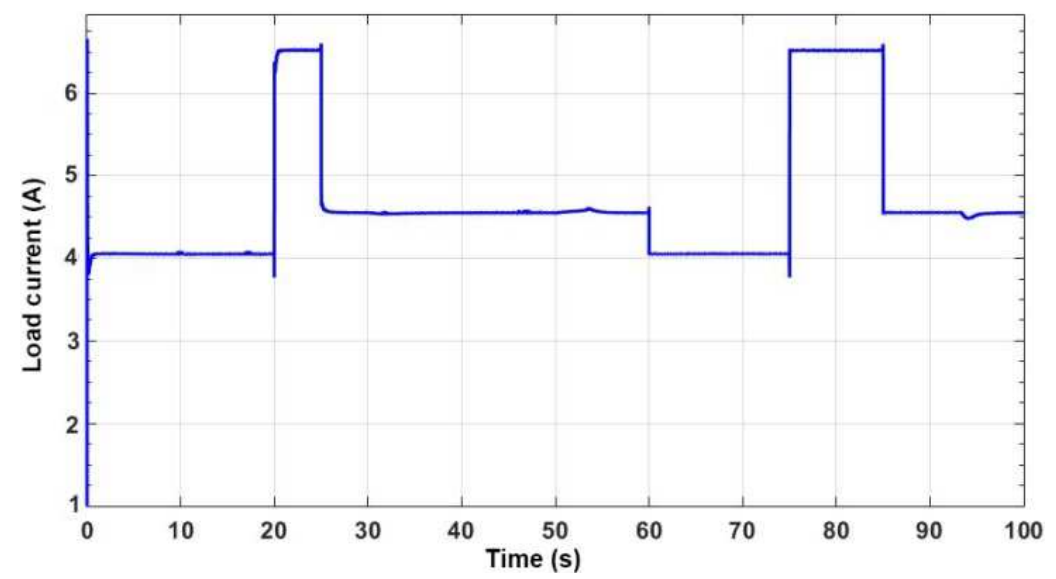

Figure 17. Load current. 


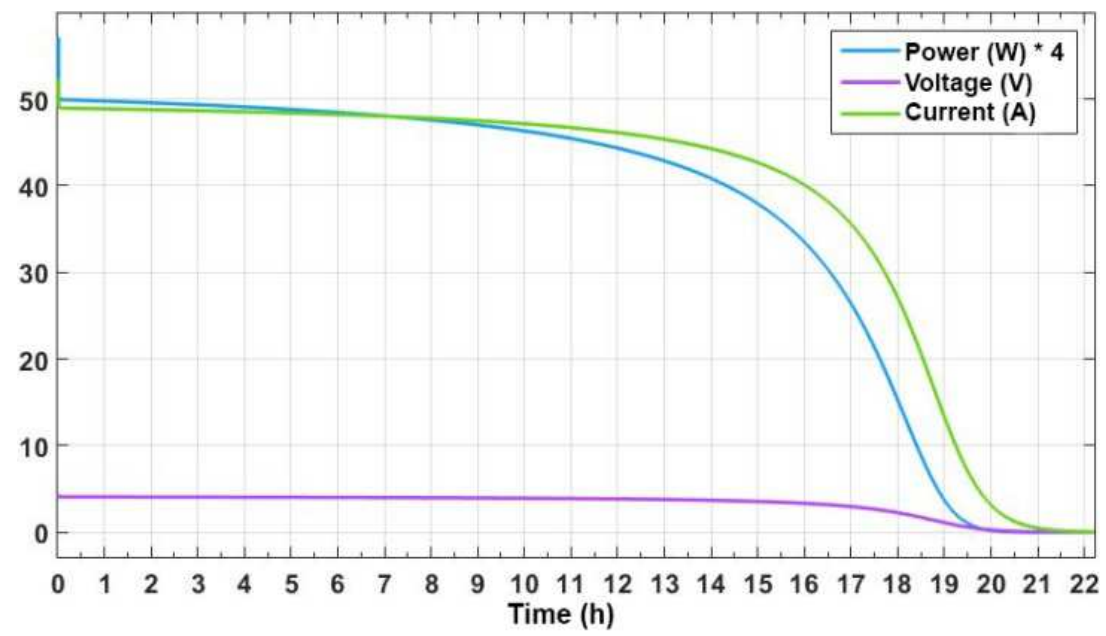

Figure 18. Battery life without generating wind turbin.

\section{Model Validation}

This section was intended to validate the model prediction presented hereby in equations (1) through (27). A comparison between the numerical model presented hereby and the experimental data collected at the fuel cell installed at the Research for Center Renewable Energy, at the Catholic University was presented in Figures 19 through .24. The wind power was used to activate the electrolyzer with 2 VDC voltage and a current of $350 \mathrm{~mA}$, power the electrolyser, where water was decomposed into hydrogen and oxygen, and stored in a small tank. Then, the stored hydrogen and oxygen were sent to the fuel cell where chemical reaction took place and resulted in a potential difference between terminals of $0.4 \mathrm{~V}$ to $0.9 \mathrm{~V}$. In Figures 19 through Figure 24 the different key performance parameters of the fuel cell were presented and discussed.

Figure 19 presented a comparison of the voltage drop in the fuel cell when the load of $0.30 \mathrm{~W}$ was connected. It can be seen that the predicted voltage decayed below experimental curve but was restored and both curves had a similar trend. The predicted voltage curve fell to $0.62 \mathrm{~V}$ and was maintained while experimental voltage curve experienced variations due to measurement error in the sensors. In Figure 20 one can see that the current had a free fall over time in both curves, and the current curve value dropped to 0.487 A while the current experimental data experienced variations that can be attributed to the measurement error of the sensors. Same trends were observed in Figures 20 through Figure 24.

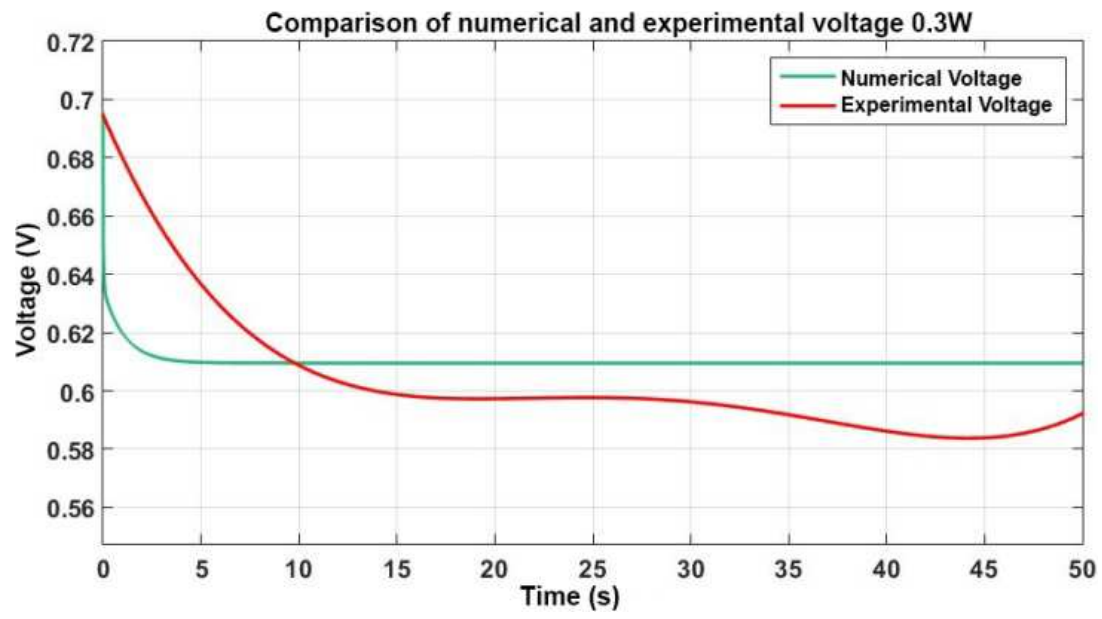

Figure 19. Comparison of experimental and numerical voltages with a load of $0.3 \mathrm{~W}$ power.

A comparison between the fuel cell voltage measured for 10 seconds, was presented in Figure 20, where the voltage dropped at a load of $0.37 \mathrm{~W}$, voltage while the experimental data were around $0.43 \mathrm{~V}$ with slight variations, and the predicted voltage curve stabilized at a voltage of $0.44 \mathrm{~V}$. Figure 22 presented a comparison between the current curve experimental data and numerical predicted results. One can see that the experimental data experienced variations in the first few seconds, but generally both experimental and numerical curves had very similar trends. In Figures 21 and 24 , it can be observed that the predicted efficiency dropped to $0.4(40 \%)$, while the efficiency experimental data had dropped to a $39.5 \%$. Therefore, we feel our model predicted well the experimental data of the key parameters of the hybrid system under investigation. 


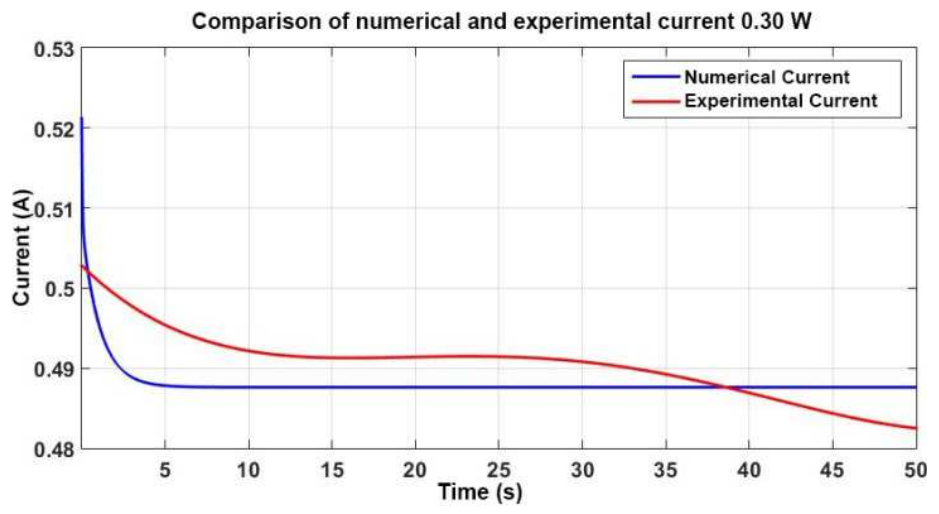

Figure 20. Comparison of load current drop with $0.3 \mathrm{~W}$ power.

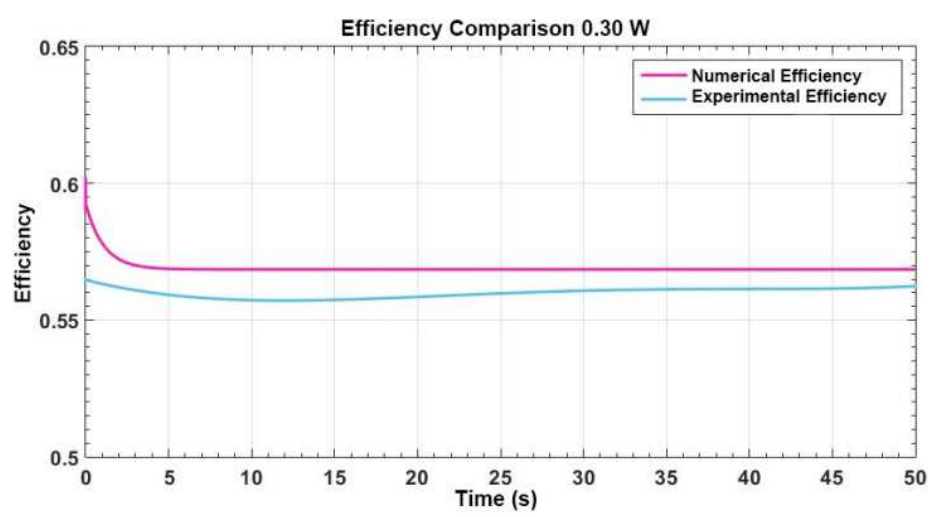

Figure 21. Comparison of efficiency with experimental data and simulation, with a load of $0.3 \mathrm{~W}$.

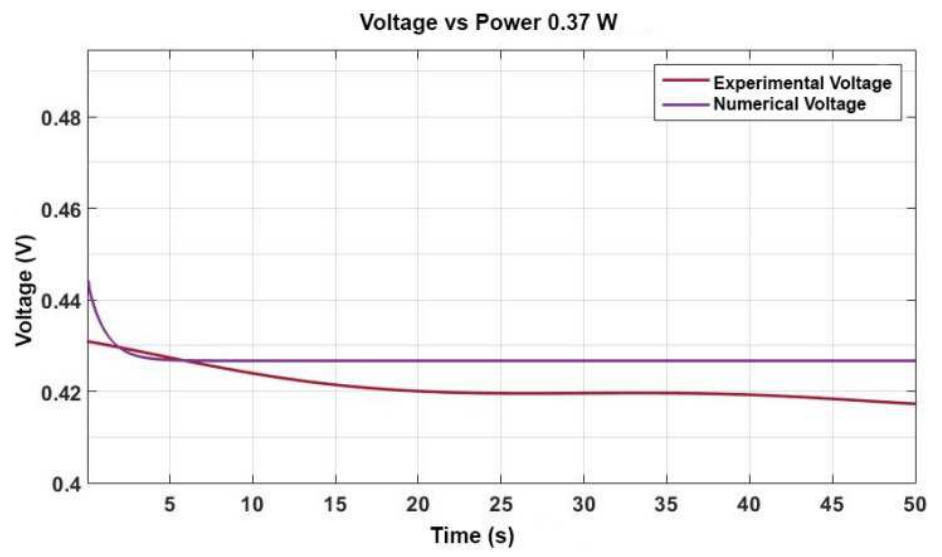

Figure 22. Comparison of fuel cell voltage efficiently, with a load of $0.37 \mathrm{~W}$.

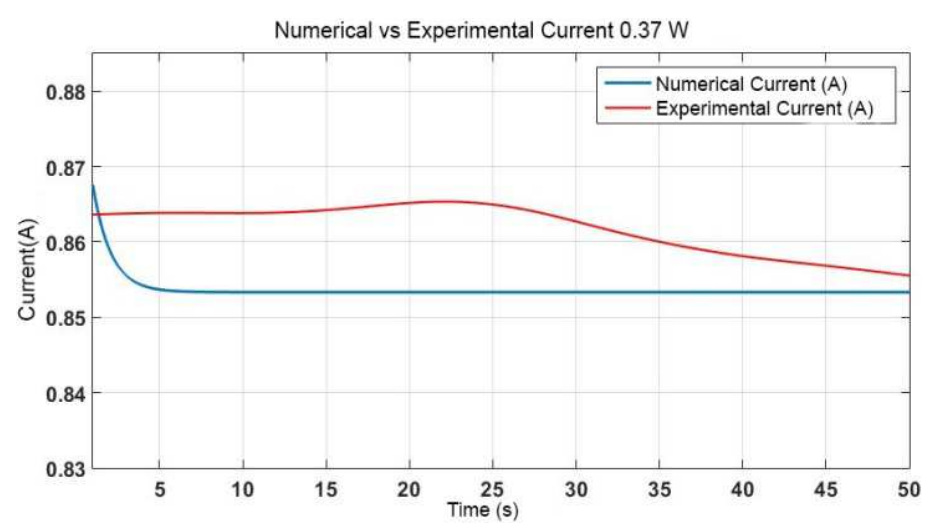

Figure 23. Comparison of numerical and experimental power with load power of $0.37 \mathrm{~W}$. 


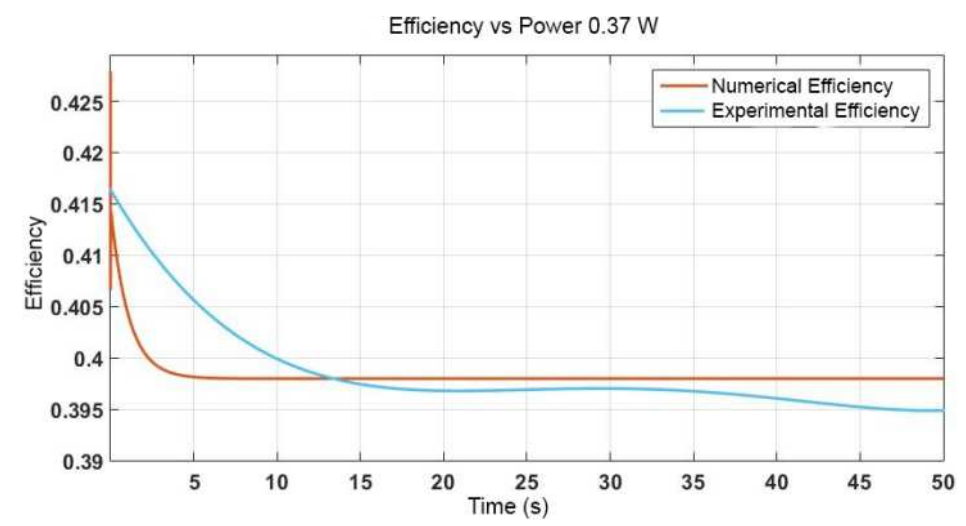

Figure 24. Comparison of experimental and numerical efficiency data with a load of $0.37 \mathrm{~W}$.

\section{Conclusions}

A hybrid system composed of a fuel cell driven by wind turbines that can be implemented in isolated or/and remote areas disconnected from national or local grid has been developed and simulated by Simulink / Matlab. The model has been developed after the conservation equations describing the behavior of the hybrid system, and the subsystems such as the fuel cell, electrolyzer and the wind turbine.

Validation of the model has been done with the experimental data obtained from the fuel cell set up at the Center for Renewable Energy (CER), demonstrated that the predicted efficiency of the hybrid system dropped to $40 \%$, while the efficiency obtained from the experimental data had dropped to a $39.5 \%$. Therefore, we feel our model predicted fairly well the experimental data of the key parameters of the hybrid system under investigation and the simulation model presented hereby was reliable and can be used as a design tool.

\section{Recommendations}

In larger fuel cell systems care should be exercised to handle the produced hydrogen and oxygen because these are highly flammable and may cause catastrophic accident, thereby, it is recommended installing gas sensors that alert, should a leak occurred in the system, Maintenance of the hydrogen generation systems must be periodic in order to ensure the pipes and equipment were in good conditions in general to ensure safety of the personnel. Further research work should be done to calculate the mass of water accumulated in the fuel cell as a result of the chemical reaction that should be validated by the measurements of amount of water built up in storage tank.

\section{Nomenclature}

HOBO: Software Software meteorological measurement PEMFC: electrolyzer proton exchange membrane PEME: Stack-fuel proton exchange membrane GIC: internal heat generation ETA: internal heat generation
PCA: heat losses in the Environment

CER: Research Center for Renewable Energy

$n_{\mathrm{H} 2}$ : Hydrogen produced in moles per second ( $\left.\mathrm{mol} / \mathrm{s}\right)$

$\eta_{F}$ : Faraday efficiency $(\%)$

$i_{e}$ : Current electrolyzer (A)

$F$ : Faraday constant $(\mathrm{C} / \mathrm{kmol})$

$T_{a}$ : is room temperature $(25 \cdot \mathrm{C})$

$M_{\mathrm{H} 2}$ : Molar mass of hydrogen $(\mathrm{kg} / \mathrm{kmol})$

$N_{H_{2}}$ : moles hydrogen per second delivered to the storage tank $(\mathrm{kmol} / \mathrm{s})$

$P_{b}:$ pressure tank $(\mathrm{Pa})$

$P_{b i}:$ initial pressure of the storage tank $(\mathrm{Pa})$

$R$ : universal gas constant (Rydberg) $(\mathrm{J} /(\mathrm{kmol} \cdot \mathrm{K}))$

$T_{b}$ : Operating temperature of the electrolyzer $(\cdot \mathrm{K})$

$V_{b}$ : Tank volume $\left(\mathrm{m}^{3}\right)$

$z$ : Compressibility factor as a function of the pressure

$C_{t}$ : Heat capacity of the fuel cell $(10000 \mathrm{~J} / \bullet \mathrm{C})$

$T$ temperature of the fuel cell (K)

$V_{\text {ucap }}$ : Ultra-capacitor voltage (V)

$P_{\mathrm{H}_{2}}$ : Hydrogen pressure (atm)

$P_{\mathrm{O}_{2}}$ : Oxygen pressure (atm)

$\mathrm{CO}_{2}$ : Oxygen concentration

$\eta_{\text {act }}$ : Activation potential of fuel cell

$R_{\text {int }}:$ internal resistance of the fuel cell

$E$ : Potencial termodinámico Nernst (V)

$v_{\text {act }}$ : Driving voltage fuel cell $(\mathrm{V})$

$R a$ : Activation resistance $(\Omega)$

$\dot{m}_{\mathrm{H}_{2}}$ : Hydrogen flow rate $(\mathrm{mol} / \mathrm{s})$

$\dot{m}_{\mathrm{O}_{2}}$ : Oxygen flow rate $(\mathrm{mol} / \mathrm{s})$

$\rho_{\mathrm{O}_{2}}$ : Oxygen density

$\rho_{\mathrm{H}_{2}}$ : Hydrogen density

$R$ : universal gas constant (atm / mol K)

$V_{\text {Fcell }}:$ Fuel cell voltage

$R_{t}:{ }^{\circ} \mathrm{C} / \mathrm{W}$

$V_{a}$ : Anode volume fuel cell (liters)

$V_{c}$ : Cathode volume fuel cell (liters)

\section{Acknowledgements}

The research work presented in this paper was made possible through the support of the Catholic University of Cuenca. The author greatly appreciates the efforts of Edwin Marin in the lengthy calculations and validation of the numerical. 


\section{References}

[1] Amphlett, J., Baumert, R., Mann, R., Peppley, B., Roberge, P., \& Harris, T. (1995). Performance Modeling of the Ballard Mark IV Solid Polymer Electrolyte Fuel Cell. I. Mechanistic Model Development, 9-15.

[2] Esmaeili, S., \& Shafiee, M. (2010). Simulation of Dynamic Response of Small Wind-Photovoltaic-Fuel Cell Hybrid Energy System. Smart Grid and Renewable Energy, 194-203.

[3] Khan, M., \& Iqbal, M. (2005). Dynamic modeling and simulation of a small wind-fuel cell hybrid energy system. Renewable Energy, 421-439.

[4] Khater, H., Abdelraouf, A., \& Beshr, M. (2011). Optimum Alkaline Electrolyzer-Proton Exchange Membrane Fuel Cell Coupling in a Residential Solar Stand-Alone Power System. International Scholarly Research Network, 13-26.

[5] Marín Calle, E. (2017). Simulación dinámica de Sistema Hibrido (Pila Combustible PEM y Panel solar Fotovoltaico) para una vivienda tipo de hasta $1200 \mathrm{Wh} /$ día. Thesis, Catholic University of Cuenca: http://dspace.ucacue.edu.ec/handle/reducacue/8128.

[6] Ogawa, T., Takeuchi, M., \& Kajikawa, Y. (2018). Analysis of Trends and Emerging Technologies in Water Electrolysis Research Based on a Computational Method: A Comparison with Fuel Cell Research. Hydrogen Economy: Technology and Social Issue, 1-24.

[7] Onar, O., Uzunoglu, M., \& Alam, M. (2006). Dynamic modeling, design and simulation of a wind/fuel cell/ultracapacitor-based hybrid power generation system. Journal of Power Sources, 707-722.

[8] Sami, S., \& Garzón, J. (2017). Thermal Analysis of Biomass / Gas Turbine and Wind Turbine Hybrid Systems for Electricity Generation and District Heating. International Journal of Current Research, 48662-48672, Volume 9, Issue.

[9] Sami, S., \& Marin Calle, E. (2018). Dynamic Modeling, and Simulation of Hybrid Solar Photovoltaic, and PEMFC Fuel Cell Power System. RA JOURNAL OF APPLIED RESEARCH, 1666-1683, ISSN: 2394-6709, DOI: 10.31142 / Slitting / v4i5.02 (pp. Volume 04 Issue: Page No.- 16661683.).

[10] Smithsonian Institution. (2020, 01 09). PEM Fuel Cell., https://americanhistory.si.edu/fuelcells/pem/pemmain.htm.

[11] UPS Battery Center, L. (2020, 01 09). UPS BATTERY
CENTER - How to Calculate Battery Capacity. upsbatterycenter.com Coincil, GW (2017). Global Wind Energy Coincil. Global Wind Energy, http://gwec.net/globalfigures/graphs/.

[12] MathWorks. (2015). MATLAB \& Simulink User's Guide. Maxwell.com. (Nd). Maxwell. www.maxwell.com.

[13] San Martin, JI, Zamora, I., Aperribay, V., \& Eguia, P. (2009). Thirteenth Regional meeting Ibero American Cigré. Analysis of the dynamic behavior of a fuel cell PEMFC. Puerto Iguazu, Argentina. teach, t. (Nd). tes teach. https://www.tes.com/lessons/BBxaBaiZx25Plg/hydrogen.

[14] A. Kirubakaran and Rajesh Nema, (2009), The PEM fuel cell system with DC/DC boost converter Design, modeling and simulation, International Journal of Recent Trends in Engineering, Vol 1, No. 3, May 2009.

[15] M. J. Khan, and T. Iqbal, (2003), Dynamic Modeling and Simulation of a Small Wind-Fuel Cell Hybrid Energy System, The 28th Annual Conference of the Solar Energy Society of Canada, August 18 to 20, 2003, Queen's University, Kingston, Canada.

[16] A. A. Salam, A. Mamemod, M Hannan, (2008), Modeling and Simulation of a PEM Fuel Cell System Under Various Temperature Conditions, 2nd WSEAS/IASME International Conference on RENEWABLE ENERGY SOURCES (RES'08) Corfu, Greece, October 26-28, 2008.

[17] Ahmed G. Abo-Khalil, Dong-Choon Lee, (2006) Dynamic Modeling and Control of Wind Turbines for Grid-Connected Wind Generation System, IEEE Annual Power Electronics Specialists Conference DOI: 10.1109/PESC.2006.1712187, 2006.

[18] ABRAM PERDANA, (2008), Dynamic Models of Wind Turbines, THESIS FOR THE DEGREE OF DOCTOR OF PHILOSOPHY, Dynamic Models of Wind Turbines A Contribution towards the Establishment of Standardized Models of Wind Turbines for Power System Stability, Division of Electric Power Engineering Department of Energy and Environment CHALMERS UNIVERSITY OF TECHNOLOGY, Goteborg, Sweden 2008.

[19] AIR403. (Nd) (2016), The New 400-Watt turbine. Arizona, USA: Southwest Windpower, Inc.

[20] https://www.mathworks.com/help/phased/ref/motionplatform. htm.

[21] https://www.hobodataloggers.com.au/hobo-energymonitoring-systems-overview. 